\title{
Antiviral activity of bovine uterus and placenta induced by Newcastle disease virus
}

\author{
[Atividade antiviral do útero e da placenta bovina induzida pelo vírus da doença de Newcastle] \\ J.B. Barreto Filho ${ }^{1}$, A.P. Marques Júnior ${ }^{2}$, R.R. Golgher ${ }^{3}$, E. Lopes ${ }^{1}$ \\ P.H.A. Carvalho ${ }^{1}$, R.O.D.S. Rossi ${ }^{1}$ \\ ${ }^{1}$ Departamento de Medicina Veterinária - UFLA \\ Caixa Postal 3037 \\ 37200-000 - Lavras, MG \\ ${ }^{2}$ Escola de Veterinária - UFMG - Belo Horizonte, MG \\ ${ }^{3}$ Centro de Pesquisas René Rachou - FIOCRUZ - Belo Horizonte, MG
}

\begin{abstract}
The antiviral activity profile of the uterus and fetal membranes from bovine placenta, induced by the Newcastle disease virus (NDV) throughout gestation, was investigated. Explants of the endometrium and caruncles were collected from the uterus, and amniochorion, allantochorion and cotyledons, from fetal placenta. Tissue cultures were induced with $\sim 6.0$ hemagglutinating units (HU) of NDV. Supernatants were concentrated 20 fold, filtered in $100 \mathrm{kDa}$ cut-off membranes and antiviral activity was titrated in MDBK x VSV system. Tissues of the uterus did not exhibit antiviral activity, while allantochorion and amniochorion produced antiviral factors throughout gestation. Antiviral factors were not related with IFN- $\alpha, \gamma, \tau$ or TNF- $\alpha$. The antiviral activity pattern observed showed to be related with the development of fetal membranes and increased at the end of pregnancy. Such data suggest that IFN genes inducible by virus are present in fetal membranes of the cow placenta and their expression is dependent on the age of gestation.
\end{abstract}

Keywords: cattle, interferon, placenta

\section{RESUMO}

Investigou-se a atividade antiviral do útero e da placenta bovina, ao longo da gestação, induzidos pelo vírus da doença de Newcastle (NDV). Explantes do endométrio e carúnculas foram colhidos do útero. Os tecidos corioamniótico, corioalantóide e cotilédones foram dissecados da placenta fetal. Os cultivos celulares foram induzidos com aproximadamente 6,0 unidades hemaglutinantes do NDV. Os sobrenadantes foram concentrados 20 vezes, filtrados em dispositivos com superficie de separação de $100 k D a$ e a atividade antiviral foi titulada em células MDBK e vírus da estomatite vesicular (VSV). Endométrio, carúnculas e cotilédones não apresentaram atividade antiviral. Corioamniótico e corioalantóide produziram fatores antivirais ao longo da gestação. Estes fatores não foram relacionados aos IFN - $\alpha, \gamma$ ou $\tau$ e nem ao TNF - $\alpha$. O padrão de produção de fatores antivirais acompanhou o desenvolvimento dos tecidos fetais e títulos mais altos foram observados no final da gestação. Estes dados sugerem que os genes de IFNs induzidos por vírus localizam-se nas membranas fetais da placenta e a expressão desses genes é dependente do estádio da gestação.

Palavras-chave: bovino, interferon, placenta

Recebido em 22 de novembro de 2005

Aceito em 8 de maio de 2007

E-mail: barreto@ufla.br 


\section{INTRODUCTION}

Morphologically, the placenta of the cow has the materno-fetal interface aggregated in placentomes consisting of fetal villi (cotyledon) enmeshed with maternal crypts (caruncle). The ruminant placenta is classified as synepitheliochorioal. The uterine epithelium is modified into a fetomaternal syncytium formed by the migration and fusion of the fetal binucleate cells with those of the uterine epithelium. These cells produce several hormones, like prostaglandins, steroids and placental lactogen (PL) (Wooding, 1992).

Type I and type II interferons are present during pregnancy in several species. In humans IFN- $\alpha$ was observed in the amniotic fluid and syncytiotrophoblast (Lebon et al., 1982; Howatson et al., 1988). In addition, in the first trimester of gestation, the presence of IFN- $\gamma$ was verified (Paulesu et al., 1994). Duc-Goiran et al. (1994) described the occurrence, in the rat, in fetal annexes (between day 10 to 21 of gestation) and in the fetus (from day 14 to birth) of a typical IFN- $\alpha$.

In the sow, IFNs- $\alpha,-\beta,-\omega$ and $\gamma$ have been identified throughout gestation (La-Bonnardière et al., 1994). IFN- $\tau$ is responsible for maternal recognition of pregnancy in the cow ( $\mathrm{Li}$ and Roberts, 1994). Nevertheless little is known about antiviral activity and IFN production by cattle placenta. NDV virus was used before as an inducer to infect primary culture of human amniotic membrane cells (Carvalho et al., 1998) and porcine peripheral blood leukocyte (Weingartl and Derbyshire, 1990) to study in vitro IFN production. For the induction, viral replication is not required and NDV envelope glycoproteins, like hemagglutinin-neuraminidase appear to be involved (Jestin and Cherbonnel, 1991; Zeng et al., 2002).

The objective of this study was to investigate the production of antiviral factors by different placental tissues in the cow, induced by the NDV.

\section{MATERIAL AND METHODS}

Placentas ( $n=15,5$ per trimester of pregnancy) were colleted in slaughterhouses and the age of gestation was determined by crown-rump length.
Explants (5g) of the amniochorion, allantochorion, cotyledon, endometrium, and caruncle were dissected, washed in Hank's saline solution 6 times and cultured in 40ml of EMEM ${ }^{1}$ for 72 hours at $37^{\circ} \mathrm{C}$ with $5 \% \mathrm{CO}_{2}$.

Cultures were induced with NDV $\left(2 \times 10^{8}\right.$ $\mathrm{EID}_{50} / \mathrm{ml}$ ) diluted in a sample containing $\sim 6.0$ HU. Virus was neutralized under denaturant conditions ( $\mathrm{pH}$ 2.0) after the induction procedures. Constitutive antiviral immunity was verified in non-induced cultures. Supernatants were concentrated 20 times and filtered in centrifugal filters of molecular weight cut-off of $100 \mathrm{kDa}^{2}$. Antiviral activity was titrated in 96 wells microplates (Ferreira et. al., 1979) using Madin Darby bovine kidney ${ }^{3}$ cells. After 12-16 hours, implants of $3.5 \times 10^{4}$ cells/well had 85 $100 \%$ of cellular confluence and monolayers were infected with vesicular stomatitis virus (VSV, $\sim 65 \mathrm{TCID}_{50}$ ). Final reading was done 48 hours after infection. In order to characterize antiviral factors, neutralization assays were done using antibodies against $\mathrm{rBoIFN}-\alpha,-\gamma,-\tau$. To verify TNF antiviral activity other experiment was done. Briefly, a standard rBo-TNF- $\alpha$ was titrated incubating samples of this cytokine with WEHI-164 cells ${ }^{4}$ in RPMI-1640 medium for 20 hours, at $37^{\circ} \mathrm{C}$ with $5 \%$ of $\mathrm{CO}_{2}$ ). MethylThiazolyl-Tetrazolium (MTT) salt was added for four hours, final reading was done at $570 \mathrm{~nm}$, and the percentage of cellular death was calculated. The TNF showed a biological activity of $400 \mathrm{ng} / \mathrm{ml}$. To verify the TNF antiviral activity, this cytokine was diluted (initial $=1: 10$ ) and added to MDBK cells $\left(3.5 \times 10^{4}\right.$ cells/ well $)$ in 96 well microplates, in triplicate. When the cells presented $85-100 \%$ confluence they were challenged with VSV and readings of the viral activity were done at 24 and 48 hours after inoculation. Data were analyzed using the SAS (1996) GENMOD procedure (PROC GENMOD) according to Der and Everitt (2002) grouping the titers by trimester of pregnancy.

\section{RESULTS AND DISCUSSION}

Tissues of the pregnant uterus (endometrium and caruncle) did not show antiviral activity, both in

\footnotetext{
${ }^{1}$ Sigma cell culture ${ }^{\mathrm{TM}}$, ST Louis, MO, USA- cat\# M0643

${ }^{2}$ Ultrafree ${ }^{\circledR}$ Millipore, Billerica, MA, USA

${ }^{3}$ MDBK - NBL-1; CCL-22 ${ }^{\mathrm{TM}}$, ATCC ${ }^{\circledR}$, Manassas, VA, USA

${ }^{4}$ CRL-1751 $^{\mathrm{TM}}$, ATCC $^{\circledR}$, Manassas, VA, USA
} 
induced and control samples. Otherwise allantochorion and amniochorion exhibited induced and constitutive antiviral activity throughout pregnancy, but cotyledons did not. The induced antiviral activity is shown in Fig. 1.

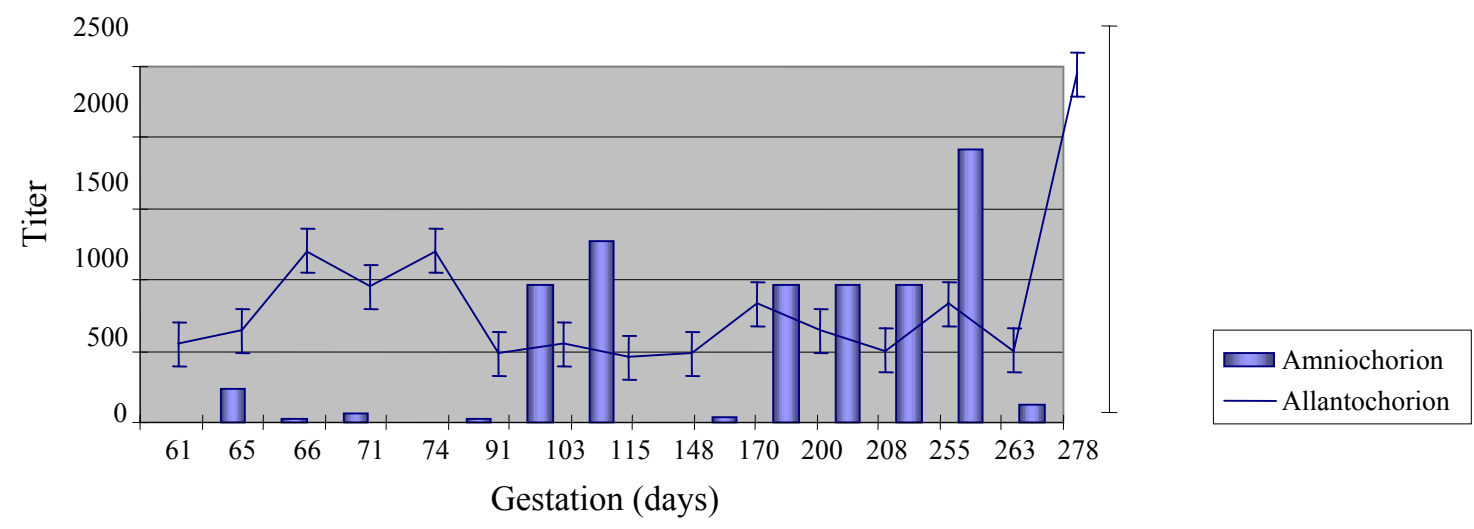

Figure 1. Amniochorion and allantochorion antiviral activity induced by Newcastle disease virus throughout gestation.

The amniochorion showed higher titers of antiviral activity in the third trimester of gestation $(\mathrm{P}=0.02)$ and between days 102 and 115 , but no statistical difference was verified $(\mathrm{P}>0.05)$ at this time. Among the 15 placentas, $12(80 \%)$ presented antiviral activity after induction. In the other side, allantochorion also showed higher titers in the last trimester of gestation $(\mathrm{P}<0.05)$. Constitutive antiviral immunity was higher in the last 180 days of gestation $(\mathrm{P}<0.05)$ but did not differ $(\mathrm{P}>0.05)$ of the induced cultures.

Between titers of the two tissues no statistical difference $(\mathrm{P}=0.76)$ was observed. Out of 15 placentas, $14(93.3 \%)$ produced antiviral factors.

Neutralization assays showed that induced antiviral factors were not antigenically related to bovine IFNs- $\alpha, \gamma$ or $\tau$. BoTNF- $\alpha$ was not able to inhibit antiviral activity in MDBK $\mathrm{X}$ VSV system. Constitutive antiviral activity in the first trimester of gestation was due to Type I IFNs $\left(\alpha_{1}\right.$ and $\tau)$. No cellular protection was verified and the cytophatic effect was $100 \%$ in all the concentrations of TNF after 48 hours. Thus, TNF was not related to the observed antiviral activity.

In the human placenta it had been demonstrated that IFN- $\beta$ was predominantly produced when stimulated by Sendai virus (Toth et al., 1990a) and double-stranded polyribonucleotide (Toth et al., 1990b). In addition, following viral stimulation first trimester human placenta produced higher levels as compared to term cultures (Aboagye-Mathiesen et al., 1993). It is possible that the antiviral activity observed in cattle placenta was due to IFN- $\beta$, since neutralization assays against this IFN were not done and denaturant conditions $(\mathrm{pH} 2.0)$ did not abolish antiviral state. Otherwise higher titers were observed in term placenta cultures in the cow (Fig. 2).

In the ewe, it has been proposed that sequential exposure of the pregnant ovine endometrium to estrogen, progesterone, IFN- $\tau$, PL and placental growth hormone $(\mathrm{GH})$ constitutes a "servomechanism" important to endometrial remodeling secretory function and uterine growth during pregnancy (Spencer and Bazer, 2004). The Type I IFN receptor subunits (IFNAR1 and IFNAR2) are expressed in all endometrial cell types in the ewe uterus with highest expression in the endometrial luminal epithelium (Rosenfeld et al., 2002). The IFN- $\tau$ induces or increases expression of interferon stimulated genes (ISGs) like ISG17 and 2'5' oligoadenylate synthase in this species and probably in the cow. However, IFN- $\tau$ was only identified in the neutralization assays in the noninduced cultures, thus it was not related to the observed antiviral activity in the NDV-induced samples. 


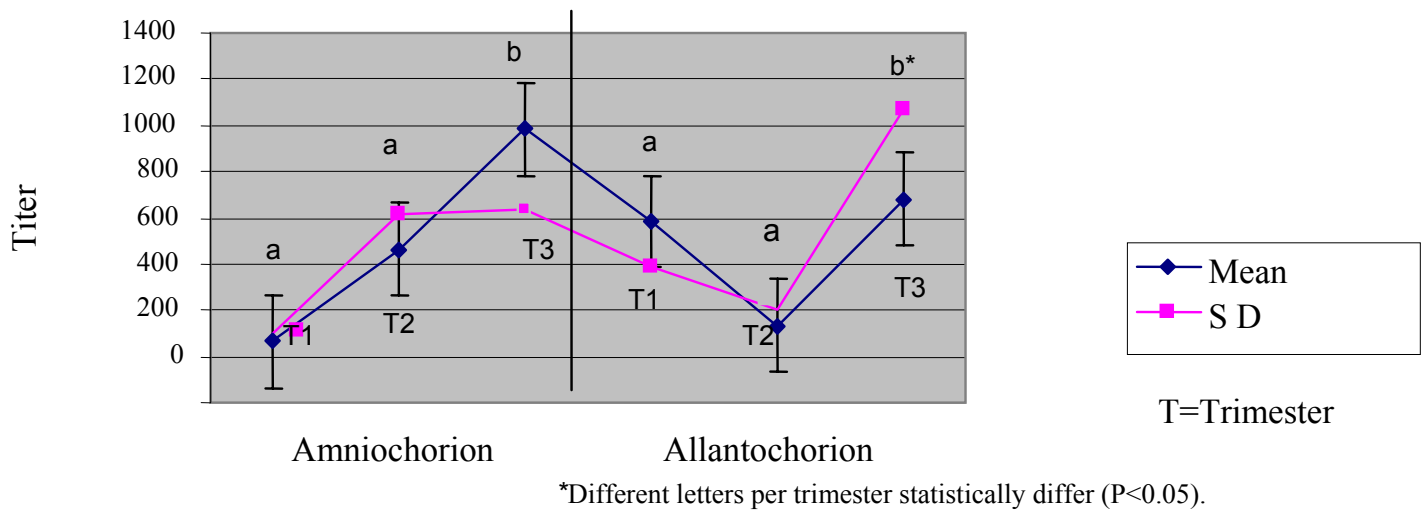

Figure 2. Induced antiviral activity exhibited by amnion and allantochorion tissues per trimester of gestation (mean $\pm \mathrm{SD})$.

In the human endometrial stromal cells, IFN- $\gamma$ antagonizes cAMP-mediated prolactin (PRL) protein and messenger RNA expression, inhibiting PRL promoter activity (Christian et al., 2001). Antiviral activity verified in cattle placenta in this work was not due to IFN- $\gamma$, since this cytokine is inactivated at $\mathrm{pH} 2.0$, condition used to eliminate NDV from the tissue cultures.

Studies in human immunodeficiency virus -1 (HIV - 1) transmission from a mother to the offspring suggest that HIV titers are low in fetus due to IFN- $\alpha$ action and hormones produced by trophoblast cells (Bourinbaiar and Nagomy, 1992; Bourinbaiar and Sylvia, 1995). IFN- $\alpha$ is present in the bovine placenta (data not shown) but it is not related to antiviral activity observed in this experiment, because antibodies antirBoIFN- $\alpha$ did not suppress the antiviral state.

Interleukins 1 (IL-1), IL-6 and IL-10 can exhibit antiviral activity, at least in some cellular systems (Paradowska et al., 1997). CD40 and FAS ligands can inhibit viral replication by different pathways (McFadden, 1995). An early pregnancy associated protein-1 (Epap-1) was reported to strongly inhibit some strains of HIV1 virus (Kondapi et al., 2002).

Although all these cytokines can show antiviral activity, the Type I IFNs are the only group of proteins, to current knowledge, resistant to $\mathrm{pH}$
2.0 denaturant conditions. Hence, data of this study strongly suggest that antiviral factors observed in the placenta fetal membranes of the cow should be related to this family of IFNs.

\section{REFERENCES}

ABOAGYE-MATHIESEN, G.; TOTH, F.D.; PETERSEN, P.M et al. Differential interferon production in human first and third trimester trophoblast cultures stimulated with viruses. Placenta, v.14, p.225-234, 1993.

BOURINBAIAR, A. S.; NAGOMY, R. Pregnancy hormones, estrogen and progesterone, prevent HIV-1 synthesis in monocytes but not in lymphocytes. Fed. Eur. Bioch. Soc. Letters, v.302, p.206-208, 1992.

BOURINBAIAR, A.S.; SYLVIA, L.H. AntiHIV effect of beta subunit of human chorionic gonadotropin ( $\beta$-hCG). Immunol. Letters, v.44, p.13-18, 1995.

CARVALHO, A.F.; SANTOS, J.R.; GENTZ, R. et al. Culture of human amniotic cells: a system to study interferon production. Placenta, v.19, p.307-314, 1998.

CHRISTIAN, M.; MARANGOS, P.; MAK, I. et al. Interferon- $\gamma$ modulates prolactin and tissue factor expression in differentiating human 
endometrial stromal cells. Endocrinology, v.142, p.3142-3151, 2001.

DER, G.; EVERITT, B.S. A handbook of statistical analyses using $S A S$. 2.ed. Boca Raton: Chapman \& Hall/ CRC, 2002. 360p.

DUC-GOIRAN, P.; ROBERT, B.; NAVANO, S. et al. Developmental control of IFN alpha expression in murine embryos. Exp. Cell Res., v.214, p.570-583, 1994.

FERREIRA, P.C.P.; PEIXOTO, M.L.P.; SILVA, M.A.N. et al. Assay of human interferons in Vero cells by several methods. J. Clin. Microbiol., v.9, p.471-475, 1979.

HOWATSON, A.G.; FARQUHARSON, M.; MEAGER, A. et al. Localization of alphainterferon in the human feto-placental unit. $J$. Endocrinol., v.119, p.531-534, 1988.

JESTIN, V.; CHERBONNELL, M. Interferoninduction in mouse spleen cells by the Newcastle disease virus (NDV) HN protein. Ann. Rech. Vet., v.22, p.365-372, 1991.

KONDAPI, A.K.; HAFIZ, M.A.; SIVARAM, T. Anti-HIV activity of a glycoprotein from first trimester placental tissue. Antiv. Res., v.54, p.4757, 2002.

La-BONNARDIÈRE, C.; LEFÈVRE, F.; CHARLEY, B. Interferon response in pigs: molecular and biological aspects. Vet. Immunol. Immunopathol., v.43, p.29-36, 1994.

LEBON, P.; GIRARD, S.; THÉPOT, F. et al. The presence of alpha-interferon in human fluid. J. Gen.Virol. v. 59, p. 393-396, 1982.

LI, J.; ROBERTS, R.M. Interferon- $\tau$ and interferon $-\alpha$ interact with the same receptors in bovine endometrium. J. Biol. Chem., v.269, p.13544-13550, 1994.

McFADDEN, G. Getting to know you: viruses meet CD40 ligand. Nat. Med., v.1, p.408-409, 1995.

PARADOWSKA, E.; BLACH-OLSZEWSKA, Z.; GEDJEL, E. Constitutive and induced cytokine production by human placenta and amniotic membrane at term. Placenta, v.18, p.441-446, 1997.

PAULESU, L.; ROMAGNOLI, R.; CINTORINO, M. et al. First trimester human trophoblast expresses both interferon-gama and interferon-gama-receptor. J. Reprod. Immunol., v.27, p.37-48, 1994.

ROSENFELD, C.H.; HAN, C.S.; ALEXENKO, A.P. et al. Expression of interferon receptor subunits, IFNAR1 and IFNAR2, in the ovine uterus. Biol. Reprod., v.67, p.847-853, 2002.

SPENCER, T.E.; BAZER, F.W. Conceptus signals for establishment and maintenance of pregnancy. Reprod. Biol. Endocrinol., v.2, p.4964, 2004.

TOTH, F.D.; JUHL, C.B.; NORSKOVLAURITSEN, N. et al. Interferon production by cultured human trophoblast induced with double stranded polyribonucleotide. J. Reprod. Immunol., v.17, p.217-227, 1990b.

TOTH, F.D.; NORSKOV-LAURITSEN, N.; JUHL, C.B. et al. Interferon production by cultured human trophoblasts and choriocarcinoma cell lines induced by Sendai virus. J. Gen. Virol., v.71, p.3067-3069, 1990a.

USER'S guide: statistics. Version 6.4. Cary, NC: SAS Institute, 1996. 168p.

WEINGARTL, H.M.; DERBYSHIRE, J.B. The induction and characterization of natural porcine interferons alpha and beta. Can. J. Vet. Res., v.54, p.349-354, 1990.

WOODING, F.B.P. Current topic: The synepitheliochorial placenta of ruminants: binucleate cell fusions and hormone production. Placenta, v.13, p.101-113, 1992.

ZENG, J.; FOURNIER, P.; SCHIRRMACHER, $\mathrm{V}$. Induction of interferon-alpha and tumor necrosis factor-related apoptosis-inducing ligand in human blood mononuclear cells by hemagglutinin-neuraminidase but not $\mathrm{F}$ protein of Newcastle disease virus. Virology, v.297, p.19-30, 2002. 